\title{
A Comparative Study of the Biocompatibility of Two Root-End Filling Materials in Rat Connective Tissue
}

\author{
Estudio Comparativo de la Biocompatibilidad de Dos Materiales \\ de Retro-Obturación en Tejido Conectivo de Rata
}

\author{
Francisco Javier Gutiérrez Cantúi ${ }^{1}$; Guadalupe Magaña Zamora²; Ricardo Oliva Rodríguez²; \\ José Obed García Cortes ${ }^{1}$; Wulfrano Sánchez Meraz ${ }^{1}$ \& Jairo Mariel Cárdenas ${ }^{1}$
}

GUTIÉRREZ, C. F. J.; MAgÃ̃A, Z. G.; OLIVA, R. R.; GARCÍA, C. J. O.; SÁNCHEZ, M. W. \& MARIEL, C. J. A comparative study of the biocompatibility of two root-end filling materials in rat connective tissue. Int. J. Morphol., 37(3):792-799, 2019.

SUMMARY: The aim of the present study was to examine the short-term biocompatibility of Endosequence Root Repair Material (ERRM) paste and white Mineral Trioxide Aggregate MTA by implanting them into polyethylene tubes in the subcutaneous connective tissue of rats. twenty five male Wistar rats, 3-4 months old, weighing 300-350 g, were used. The tubes were implanted dorsally into the subcutaneous connective tissues of the rats. Five animals were sacrificed at five examination time points: 1, 3, 5, 7 and 15 days. The connective tissues containing the implants were excised. These sections were studied qualitatively and quantitatively using a light microscope. An average value for each group was obtained by averaging the sum of all inflammatory cells counted in 10 randomly selected, separate areas. For the ERRM group: There was a significant increase in the number of inflammatory cells on days 1-3 and on days 5-7 ( $\mathrm{P} \leq 0.003$ and $\mathrm{P} \leq 0.024)$. In the WHITE MTA group, the mean values of the sum of the inflammatory cells during the periods 1-3 days and 5-7 days were statistically significant $(\mathrm{P} \leq 0.001$ and $\mathrm{P} \leq 0.044$, respectively) and the XILOPERCHA group: Difference was observed significant in the value of the sum of inflammatory cells during the period of 3-5 days $(\mathrm{P} \leq 0.05)$. According to the results it can be concluded that both, ERRM as MTA, caused an inflammatory reaction, which decreased over time; suggesting that both materials are biocompatible; showing however the presence of a higher organization of collagen fibers around the implants of ERRM.

KEY WORDS: Restorative materials; White MTA; Biocompatibility; ERRM.

\section{INTRODUCTION}

Endodontic restorative materials are commonly used in apical resection procedures and the sealing of root perforations. Therefore, an ideal repair material should be biocompatible, dimensionally stable, easy to handle, and radiopaque; should have sufficient hardness and compressive strength; and should not be affected by the moisture of periradicular tissue fluids. It is also desirable that the material acts as an inductor or conductor of bone apposition (Chong \& Pitt Ford, 2005).

Many products, such as amalgam, zinc oxide-eugenol cements, glass ionomer cements and composite resins have been used as restorative materials. Since it was developed at Loma Linda University in the 1990s, mineral trioxide aggregate (MTA), a material based on Portland cement, has gained ground as a repair material because it is recognized as a bioactive material that can induce hard-tissue deposition and is also biocompatible (Camilleri \& Pitt Ford, 2006).
MTA is commercially available as ProRoot MTA (Dentsply Tulsa Dental Specialties, Tulsa, OK, USA) or as MTA-Angelus (Angelus Soluções Dentistry, Londrina, Brazil), both in gray and white presentations.

MTA powder consists of fine hydrophilic particles of tricalcium silicate, dicalcium silicate, bismuth oxide, tricalcium aluminate and calcium sulfate, which set upon hydration (Parirokh et al., 2010). MTA has been a very commonly used material for retro-sealing, perforation repair and apexification, being considered one of the most biocompatible materials that can be used with substantial certainty as to its biological behavior. However, over time, this material's characteristics have begun to be considered less than ideal due to a very long setting time and difficulty in maintaining the consistency of the mixture as well as the presence of heavy metal traces in its composition, relatively limited availability in certain regions, the absence of a solvent for its removal and related difficulties.

\footnotetext{
${ }^{1}$ Department of Morphology, Faculty of Dentistry, University of San Luis Potosí, San Luis Potosí, México.

${ }^{2}$ Masters of Endodontics, Faculty of Dentistry, University of San Luis Potosí, San Luis Potosí, México.
} 
There have been various efforts to overcome these drawbacks; however, introducing new variations into the composition of MTA or using additives can affect its best characteristics and biological behavior.

Recently, Endosequence Root Repair Material (ERRM; Brasseler USA, Savannah, GA, USA) has been developed as a premixed bioceramic material, ready for use in two presentations: putty and paste. This material is recommended for applications such as apical surgery, repair of perforations and direct pulp capping. According to the manufacturer, both presentations have a composition based on calcium silicates, zirconium oxide, tantalum oxide and monobasic calcium phosphate.

It has been reported that ERRM has excellent physical and biological properties and ease of handling. This material is also hydrophilic, insoluble, radiopaque, and aluminum free; has a high $\mathrm{pH}$; requires moisture to set; and has a working time of over $30 \mathrm{~min}$ and a setting time of $4 \mathrm{hrs}$ under normal conditions (Parirokh et al., 2011).

Several studies have compared the performance of ERRM and MTA in terms of cytotoxicity in cell cultures and, to a lesser extent, for biocompatibility in animal models (Damas et al., 2011; Shokouhinejad et al., 2012).

The aim of the present study was to histopathologically examine the short-term biocompatibility of ERRM paste and white MTA by implanting them into the subcutaneous connective tissue of rats.

\section{MATERIAL AND METHOD}

In total, 25 male Wistar rats, 3-4 months old, weighing 300-350 g, were used. The Research Ethics Committee of the Faculty of Stomatology of the Autonomous University of San Luis Potosi approved the study protocol (registry CEI-FE-06-013).

The rats were anesthetized using a regimen consisting of ketamine hydrochloride (40-87 mg kg-1) and xylazine hydrochloride (5-13 mg kg-1).

Polyethylene tubes with an inner diameter of $2 \mathrm{~mm}$ and an outer diameter of $4 \mathrm{~mm}$ were cut into pieces of $6 \mathrm{~mm}$ in length. One end was closed with heat, and then, the pieces were sterilized with hydrogen peroxide gas plasma at a low temperature (Sterrad 100NX, ASP, Irvine, CA, USA). For each animal, three tubes were used as carriers for the two tested materials and the positive control. MTA was prepared according to the manufacturer's instructions and then introduced into the tubes. ERRM (Brasseler USA, Savannah, GA, USA) was introduced into the tubes using a syringe. Xilopercha (positive control) was prepared by mixing guttapercha with xylene until a paste was made and then introduced into the tubes; one empty tube served as the negative control.

The tubes were implanted dorsally into the subcutaneous connective tissues of the rats. The dorsal skin of the animals was shaved and disinfected using $10 \%$ iodine solution, and two $2-\mathrm{cm}$ incisions were made on each side of the dorsal midline of each rat using a no. 15 blade (Aesculap AG and Co. KG, Tutlingen, Germany). A pocket-like space was created in the skin by blunt dissection, into which polyethylene tubes were implanted. To prevent contact and interference of the tissue reactions, the open ends of the tubes containing the experimental materials were placed in the cephalic direction, and the open ends of the tubes of the control materials were placed in the caudal direction. The skin was closed with a $4 / 0$ silk suture.

Five animals were sacrificed at five examination time points: 1, 3, 5, 7 and 15 days. After shaving the areas containing the implants, the connective tissues containing the implants were excised. The specimens were kept in $10 \%$ formalin for 1 week. Sections of 5- $\mu \mathrm{m}$ thickness were taken from specimens embedded in paraffin blocks and stained with hematoxylin and eosin for histological evaluation to verify the inflammatory response or with Masson trichrome stain to assess the presence of collagen fibers and to determine the approximate time at which the initiation of repair occurs. These sections were studied qualitatively and quantitatively using a light microscope (Leica 1000) at x10, x20, and x100 magnifications. The observer was blinded to the group origin of the tissue.

An average value for each group was obtained by averaging the sum of all inflammatory cells (polymorphonuclear leukocytes, plasma cells, lymphocytes, macrophages and giant cells) counted in 10 randomly selected, separate areas. The inflammatory reactions were also rated and scored as 0 , no or few inflammatory cells (no reaction); 1 , $<25$ cells (mild reaction); 2, 25-125 cells (moderate reaction); or 3,125 cells (severe reaction). The presence or absence of collagen or procollagen fibers was also noted.

Statistical analysis was carried out in the statistical package MINITAB version 17. Results are expressed as mean \pm SD. The assumption of normal distribution of the data was confirmed through Shapiro-Wilk tests, the results were statistically analyzed with one-way ANOVA and Tukey's multiple comparisons test for comparison of the severity of inflammation at different intervals and for the different materials. A value of $p<0.05$ was considered to be statistically significant. 


\section{RESULTS}

CONTROL group. At the 1-day time point, a mild inflammatory reaction, with edema, inflammatory cell infiltration and degraded collagen, was observed, whereas at the 3-day time point, a decrease in inflammatory cells and increased production of procollagen were noted, (Fig. $1 \mathrm{C})$. At the 5-day time point, the number and thickness of procollagen fibers and fibroblast activity, without the presence of edema, were observed (Fig. 1G), whereas at the 7-day time point, a clear increase in the number and thickness of collagen fibers, with a marked decrease in the inflammatory cell number, marked fibroblast activity and increased organization of collagen fibers, was observed, (Fig. 2C). At the 15-day time point, the presence of inflammatory cells was minimal, with formation and organization of collagen fibers, indicating the absence of an inflammatory reaction or tissue repair (Fig. 2G).

The average value of the sum of inflammatory cells for the control group in the periods from 1-3 days and from 3-5 days showed no significant difference $(\mathrm{P} \geq 0.05)$, but the average did show a statistically significant difference in the periods from 5-7 days and from 7-15 days $(\mathrm{P} \leq 0.002$ and $\mathrm{P}$ $\leq 0.001$, respectively) (Table I).

ERRM group. By day 1, slight edema, the presence of inflammatory cells and degradation of collagen fibers were observed, whereas at the 3-day time point, there was a clear decrease in inflammatory cells (Fig. 1B). At the 5-day time point, increased collagen production was noted, with higher density of the fibers in comparison with the density in the other groups, (Fig. 1F). At the 7-day time point, mature collagen fibers were observed in addition to more organized neoformation of procollagen and a marked decrease in inflammatory cells, (Fig 2B). At the 15-day time point, despite the inflammatory reaction, the production of collagen fibers and their organization were clear, suggesting a more rapid period of repair than in the MTA group, (Fig. 2F).

A statistically significant increase was observed in the number of inflammatory cells from days 1-3 and from days 5-7 ( $\mathrm{P} \leq 0.003$ and $\mathrm{P} \leq 0.024$, respectively), and no significant increase was observed in the periods from 3-5 days and from 7-15 days $(\mathrm{P} \geq 0.05)$ (Table I).

WHITE MTA group. The inflammatory reaction was moderate, with edema and an increased number of inflammatory cells, degraded collagen fibers and fibroblast proliferation at the 1-day time point. By day 3, the number of inflammatory cells had decreased, and collagen production had increased, but the number and density of the fibers were lower than in the ERRM group, (Fig. 1A). At the 5-day time point, fibroblast proliferation, with neoformation of procollagen and angiogenesis, was observed, but the collagen fibers were not mature, (Fig. 1E). At the 7-day time point, although there was a decrease in the number of inflammatory cells, there was no substantial fibroblast activity, as the number of collagen fibers was even lower than in the other groups. The presence of procollagen was also noted, which indicated the process of tissue repair (Fig. 2A). By day 15, despite a clear decrease in the number of inflammatory cells and an increased fibroblast population and angiogenesis, organization of the collagen fibers was not observed, with only the presence of procollagen noted in the sections, in contrast to that observed in the ERRM group (Fig. 2E).

The mean values of the sum of inflammatory cells over the periods from 1-3 days and from 5-7 days were statistically significant $(\mathrm{P} \leq 0.001$ and $\mathrm{P} \leq 0.044$, respectively), with non-significant $(\mathrm{P} \geq 0.05)$ values over the periods from 3-5 days and from 7-15 days (Table I).

XILOPERCHA group. There was an inflammatory reaction characterized by accentuated edema and a large presence of inflammatory cells by the 1-day time point. At the 3-day time point, the number of inflammatory cells remained high, even though there was proliferation of fibroblasts, (figure 1D). At day 5 , the edema continued, with inflammatory infiltrates, (Fig. $1 \mathrm{H})$, and at the 7-day time point, the number of inflammatory cells was higher than in, the other groups and did not show large numbers of collagen fibers. Additionally, presence of fibroblasts and new formation of procollagen fibers were observed, (Fig. 2D). At the 15-day time point, the inflammatory response continued, and the formation of collagen fibers was poor, as was angiogenesis, although fibroblast activity and procollagen were present in the tissue (Fig. 2H).

There was a statistically significant increase in the value of the sum of inflammatory cells for the period from 3-5 days $(\mathrm{P} \leq 0.05)$ but not for 1-3 days or 5-7 days or at 715 days $(\mathrm{P} \geq 0.05)$ (Table I).

Comparison between the four groups at the 1-day time point. One-way ANOVA did not show a statistically significant difference in the number of inflammatory cells between the experimental groups and compared with the Xilopercha group $(\mathrm{P}>0.05)$. Relative to the Xilopercha group, the number of inflammatory cells was higher than in the other groups, showing a significant difference $(\mathrm{p}<0.05)$ (Table II).

Tukey's multiple range test, used to determine differences between the four groups, revealed that there was statistically significant difference between the Xilopercha group and the other groups (Table I). 

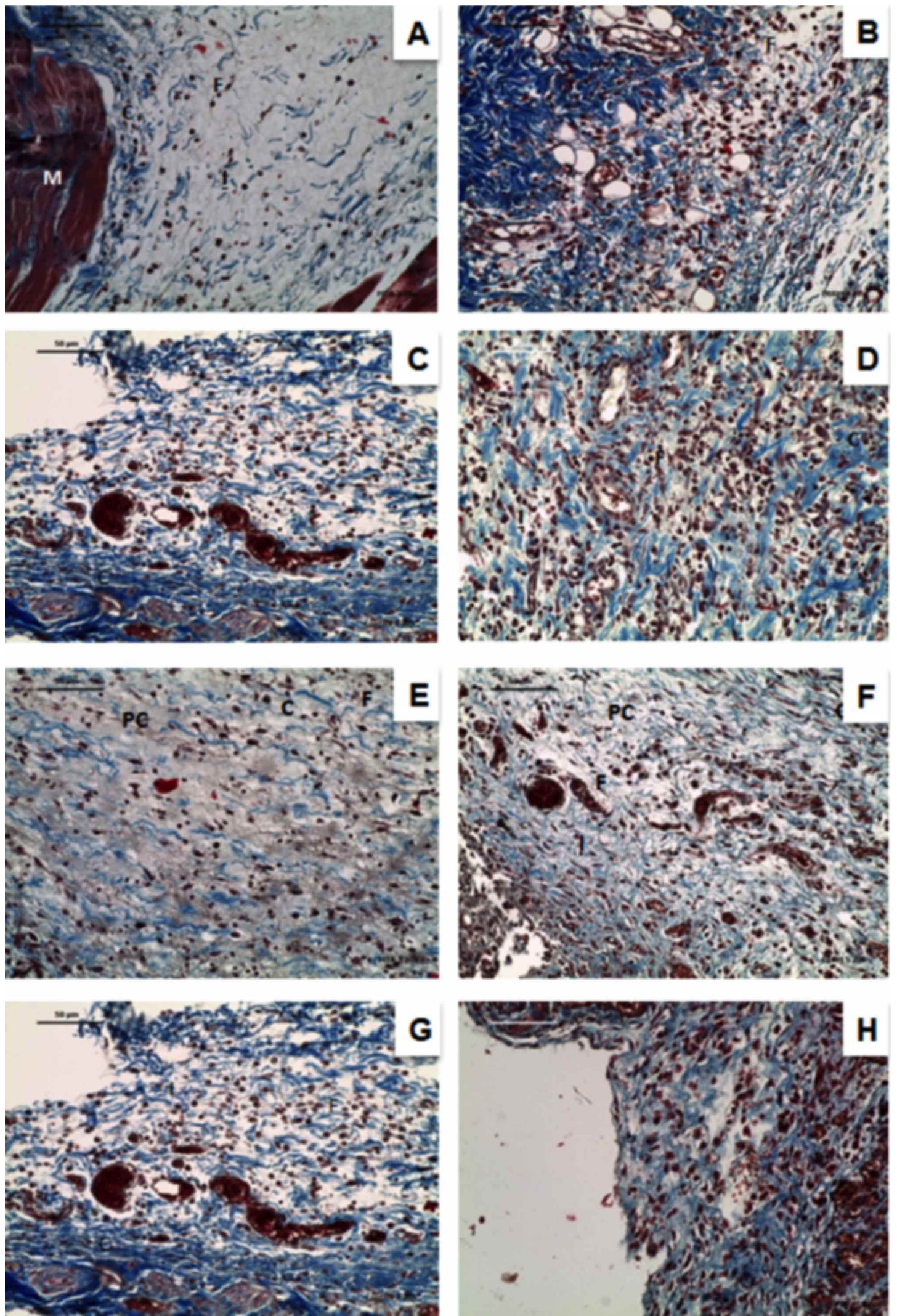

Fig. 1. Masson trichrome staining of histological sections (20x). Day 3: (A) White MTA, (B) ERRM, (C) Negative control, (D) Xilopercha. Day 5: (E) White MTA, (F) ERRM, (G) Negative control, (H) Xilopercha. 

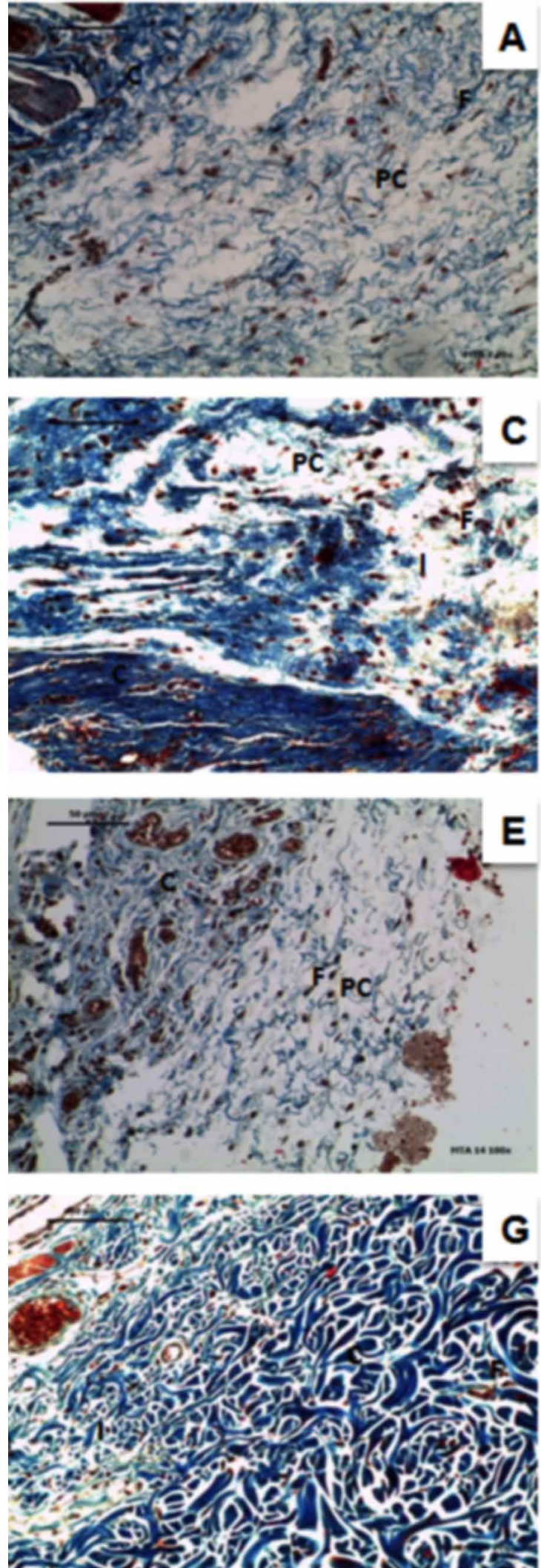

Fig. 2. Masson trichrome staining of histological sections (20x). Day 7: (A) White MTA, (B) ERRM, (C) Negative control, (D) Xilopercha. Day 15: (E) White MTA, (F) ERRM, (G) Negative control, (H) Xilopercha.
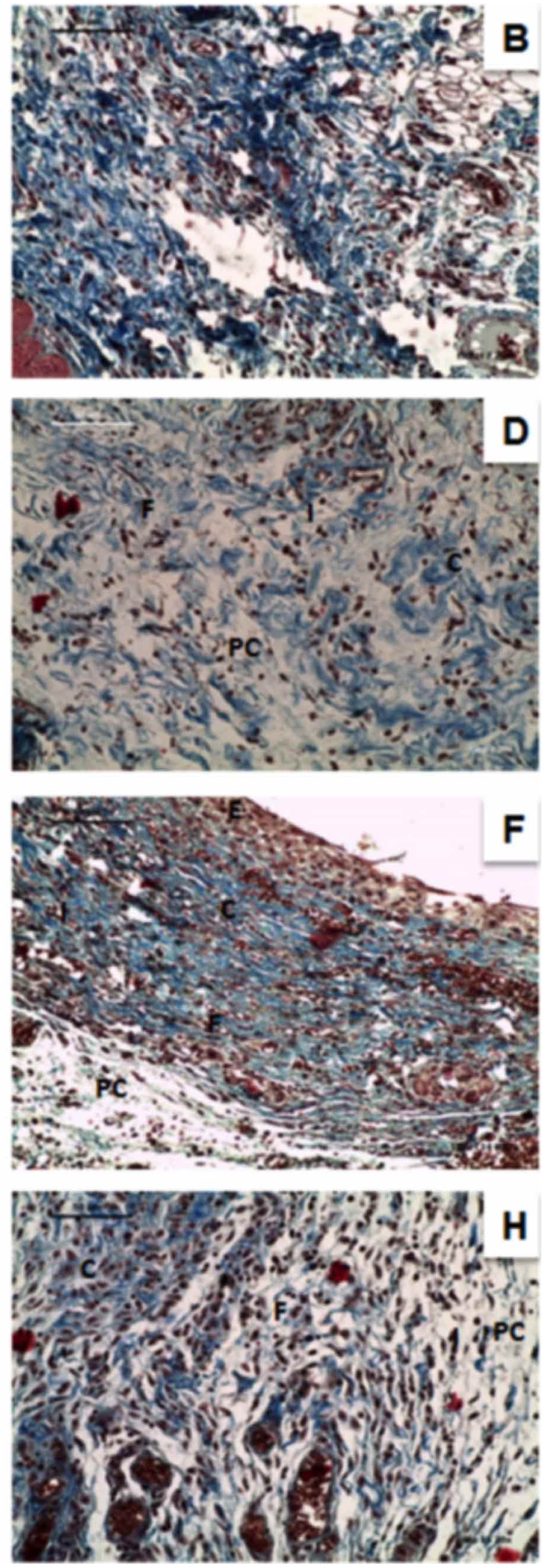
GUTIÉRREZ, C. F. J.; MAGAÑA, Z. G.; OLIVA, R. R.; GARCÍA, C. J. O.; SÁNCHEZ, M. W. \& MARIEL, C. J. A comparative study of the biocompatibility of two root-end filling materials in rat connective tissue. Int. J. Morphol., 37(3):792-799, 2019

Table I. P values between groups at different times.

\begin{tabular}{|c|c|c|c|c|c|}
\hline & \multicolumn{2}{|l|}{$\mathrm{p}$ Value } & \multicolumn{2}{|l|}{$\mathrm{p}$ Value } & \multirow[t]{2}{*}{$\mathrm{p}$ Value } \\
\hline 1 day & & & & & \\
\hline Xilopercha- White MTA & 0.1727 & Control-White MTA & 0.0002 & ERRM-White MTA & 0.6646 \\
\hline $\begin{array}{l}\text { Control-Xilopercha } \\
3 \text { day }\end{array}$ & 0.0120 & ERRM-Xilopercha & 0.7386 & ERRM-Control & 0.0015 \\
\hline Xilopercha- White MTA & 0.0001 & Control-White MTA & 0.9993 & ERRM-White MTA & 0.7550 \\
\hline Control-Xilopercha & 0.0001 & ERRM-Xilopercha & 0.0007 & ERRM-Control & 0.8203 \\
\hline 5 day & & & & & \\
\hline Xilopercha- White MTA & 0.0834 & Control-White MTA & 0.9821 & ERRM-White MTA & 0.9998 \\
\hline $\begin{array}{l}\text { Control-Xilopercha } \\
7 \text { day }\end{array}$ & 0.1602 & ERRM-Xilopercha & 0.0954 & ERRM-Control & 0.9906 \\
\hline Xilopercha- White MTA & 0.0001 & Control-White MTA & 0.9894 & ERRM-White MTA & 0.7916 \\
\hline $\begin{array}{l}\text { Control-Xilopercha } \\
15 \text { day }\end{array}$ & 0.0001 & ERRM-Xilopercha & 0.0002 & ERRM-Control & 0.6151 \\
\hline Xilopercha- White MTA & 0.0001 & Control-White MTA & 0.0004 & ERRM-White MTA & 0.9245 \\
\hline Control-Xilopercha & 0.0001 & ERRM-Xilopercha & 0.0001 & ERRM-Control & 0.0001 \\
\hline
\end{tabular}

Significant $\mathrm{p}$ values of different groups in each of the treatment days are shown in bold font.

Comparison between the four groups at the 3-day time point. In the samples taken after 3 days, there was no difference between the experimental groups and the control group ( $p>0.05$ ); however, statistically significant differences between the Xilopercha group and the other three groups were observed: Xilopercha vs. White MTA, $\mathrm{p}<0.0001$; Xilopercha vs. ERRM, p<0.0007; and Xilopercha vs. Control, $\mathrm{p}<0.0001$ (Table II).

Comparison between the four groups at the 5-day time point. In the four groups, a decrease in inflammatory cells was observed. However, edema and inflammatory infiltrate were still observed in the Xilopercha group, without a statistically significant difference between groups $(p>0.05)$ (Table II).
Comparison between the four groups at the 7-day time point. No statistically significant difference between the experimental groups and the control group ( $p>0.05)$ was shown; a significant difference was only shown between the Xilopercha group and the remaining three groups ( $p<0.05)$. Significant differences were as follows: Xilopercha vs. MTA, p <0.0001; Xilopercha vs. ERRM, p <0.0002; and Xilopercha vs. Control, $\mathrm{p}<0.0001$ (Table II).

Comparison between the four groups at the 15-day time point. The results showed statistically significant differences between the control group and the other three groups; however, between the two experimental groups, there was no statistically significant difference $(\mathrm{p}>0.9245)$ (Table II).

Table II. Mean value and standard deviation of the sum inflamatory cells for all materials at all test periods.

\begin{tabular}{|c|c|c|c|c|c|c|c|c|c|}
\hline Material & 1 day & $\begin{array}{l}\mathrm{p} \text { Value: } \\
1-3 \text { days }\end{array}$ & 3 days & $\begin{array}{l}\text { p Value: } \\
\text { 3-5 days }\end{array}$ & 5 days & $\begin{array}{l}\text { p Value: } \\
5-7 \text { days }\end{array}$ & 7 days & $\begin{array}{l}\mathrm{p} \text { Value: } \\
7-15 \text { days }\end{array}$ & 15 days \\
\hline CONTROL & $12.6 \pm 6.024$ & $\mathrm{P} \geq 0.050$ & $10.4 \pm 2.509$ & $\mathrm{P} \geq 0.05$ & $12.6 \pm 3.049$ & $\mathrm{P} \leq 0.002$ & $6 \pm 1.224$ & $\mathrm{P} \leq 0.001$ & $1 \pm 1$ \\
\hline ERRM & $27 \pm 4.301$ & $\mathrm{P} \leq 0.003$ & $13.2 \pm 5.761$ & $\mathrm{P} \geq 0.05$ & $11.8 \pm 2.683$ & $\mathrm{P} \leq 0.024$ & $7.6 \pm 2.073$ & $\mathrm{P} \geq 0.050$ & $7.8 \pm 1.095$ \\
\hline WHITE MTA & $30.6 \pm 3.209$ & $\mathrm{P} \leq 0.001$ & $10 \pm 2.345$ & $\mathrm{P} \geq 0.05$ & $11.6 \pm 3.049$ & $\mathrm{P} \leq 0.044$ & $6.4 \pm 2.073$ & $\mathrm{P} \geq 0.050$ & $8.6 \pm 2.607$ \\
\hline XILOPERCHA & $23.8 \pm 5.718$ & $\mathrm{P} \geq 0.050$ & $29.2 \pm 7.661$ & $\mathrm{P} \leq 0.05$ & $18.6 \pm 6.877$ & $\mathrm{P} \geq 0.05$ & $14.8 \pm 2.588$ & $\mathrm{P} \geq 0.050$ & $17.2 \pm 2.774$ \\
\hline $\mathrm{p}$ Value & 0.00019 & & $4.5 \mathrm{e}-05$ & & 0.06 & & $1.1 \mathrm{e}-05$ & & $1.1 \mathrm{e}-05$ \\
\hline
\end{tabular}

Significant $\mathrm{p}$ values with ANOVA test are shown in bold font. Values within the same period showed significant differences (p Values) with Tukey's multiple comparison test.

\section{DISCUSSION}

Biocompatibility is one of the most important features of endodontic repair materials; being in direct contact with the tissues causes initial irritation, which should ideally decrease in the shortest time possible. Because in vitro studies provide no information about tissue responses, in the present study, a biocompatibility test was performed using an in vivo 
assay to evaluate the response of the subcutaneous tissue of rats after implantation of a material into the connective tissue within polyethylene tubes. These tubes are commonly used in such trials and, in contrast to models in which the material is injected directly, prevent the spread of connective tissue and simulate the clinical conditions of the root canal (Olsson et al., 1981; Khashaba et al., 2011).

Xilopercha was used as a positive control due to the toxicity caused by xylene, as has been previously reported (Morse et al., 1984a,b).

The method for assessing inflammation was performed according to previous implantation studies to evaluate the tissue reaction by quantifying the inflammatory cells in the tissue that is in contact with the polyethylene tubes (Hammad et al., 2011).

In this study, the results of biopsies taken after 1 day showed no difference between the experimental groups but did show a difference from the control group, in which the number of inflammatory cells was significantly lower than in the other groups. The mild inflammatory reaction caused in this group was consistent with previous studies in which the inflammatory response in the control group was attributed to trauma during surgical placement of the tubes (Shahi et al., 2006).

However, at the 3-day time point, a statistically significant difference was observed, with a decrease in the number of inflammatory cells in the three other groups compared with the Xilopercha group, in which the number of inflammatory cells showed an increase. These results coincide with those of Morse, who showed a severe inflammatory reaction after placing Xilopercha in connective tissue, suggesting that Xilopercha increases the reaction in the subcutaneous tissue over time; the tissue reaction to Xilopercha over 6 hrs showed a milder inflammatory reaction than at 48 hrs after injection into the subcutaneous tissue (Morse et al., 1984a,b). At the 5-day time point, the control groups and the ERRM group showed a decrease in the number of inflammatory cells, whereas the MTA group showed a rise. These results agree with those reported by Shahi et al., who described an increase in the inflammatory reaction between the 3-day and the 7-day time points. This could have been the result of a gradual release of calcium hydroxide and a gradual reaction with tissue fluids. However, a statistically significant difference was not shown between the four groups (Shahi et al.).

A decrease in the number of inflammatory cells in the four groups was observed at the 7-day time point. However, there was a statistically significant difference between the Xilopercha group and the other three groups, suggesting that the experimental groups, despite an initial inflammatory response, had the ability to promote tissue regeneration because the presence of collagen fibers and procollagen was noted. However, in the ERRM group, mature collagen fibers with better organization were observed, suggesting that the repair time in the case of applying ERRM is shorter than in the case of applying MTA. In contrast to these groups, in the Xilopercha group, a moderate inflammatory reaction was observed, which is explained by the toxicity presented by xylene in connective tissue. The results of this study differ from those obtained by Yaltirik et al. (2004), who observed the presence of areas of necrosis after implanting MTA into subcutaneous tissue, a reaction that continued until day 15 . In our study, there was no necrosis in any of the samples from the experimental groups (Yaltirik et al.).

In the results at the 15-day time point, a decrease in the number of inflammatory cells in all groups was shown, with statistically significant differences between the two control groups and the experimental groups. However, there was no difference between the two experimental groups. These results are consistent with in vitro studies carried out previously, in which it was suggested that ERRM is as biocompatible as MTA according to cell viability tests. In these tests, no significant differences were present regarding the viability of gingival fibroblasts and morphological changes in the cells (Damas et al.; Ma et al., 2011).

The inflammatory reaction in both experimental groups may also be attributed to the surgical process, in addition to the fact that both materials are able to induce the expression of proinflammatory cytokines such as IL-1, IL-6 and IL-8 as well as small amounts of TNF. However, in a previous study by Ciasca et al. (2012), no statistically significant difference was found between the two materials, in addition to the fact that the production of cytokines decreased in both groups over an evaluation period of $48 \mathrm{~h}$.

The results obtained in the present study indicated that ERRM and MTA provoked an inflammatory reaction to variable degrees. This reaction decreased throughout the 15-day testing period, suggesting that both materials are biocompatible. However, the presence of collagen fibers in greater numbers and with better organization was observed in the tissue around the implanted ERRM.

ACKNOWLEDGEMENTS. Guadalupe Magaña Zamora was supported by the CONACYT scholarship for masters studies. To ISC. Edgardo Martinez Martín Del Campo, Professor of the Faculty of Stomatology of the UASLP, for his technical support. 
GUTIÉRREZ, C. F. J.; MAGAÑA, Z. G.; OLIVA, R. R.; GARCÍA, C. J. O.; SÁNCHEZ, M. W. \& MARIEL, C. J. Estudio comparativo de la biocompatibilidad de dos materiales de retroobturación en tejido conectivo de rata. Int. J. Morphol., 37(3):792$799,2019$.

RESUMEN: El objetivo del presente estudio fue evaluar la biocompatibilidad a corto plazo de Material de Reparación de la Raíz Endodóntica (MRRE) y el agregado de trióxido mineral (AgTM), implantándolos dentro de tubos de polietileno en el tejido conectivo subcutáneo de ratas. Se usaron 25 ratas Wistar macho, de 3-4 meses de edad, con peso de 300 a 350 g. Los tubos fueron implantados en el tejido conectivo subcutáneo del dorso de las ratas. Cinco animales fueron sacrificados en cada uno de los siguientes períodos de tiempo: 1, 3, 5, 7, y 15 días. El tejido conectivo con los implantes fue escindido y seccionado. Los cortes se evaluaron cualitativa y cuantitativamente mediante microscopio óptico. Se obtuvo un valor para cada grupo resultado al promediar la suma de las células inflamatorias contadas en 10 áreas separadas seleccionadas aleatoriamente. Para el grupo de MRRE; hubo un incremento significativo en la cantidad de células inflamatorias entre los días $1-3$ y 5-7 ( $\mathrm{p} \leq 0,003$ y $\mathrm{p} \leq 0,024)$. En el grupo de AgTM blanco, los valores promedio de la suma de células inflamatorias entre los períodos 1-3 días, y 5-7 días mostraron ser estadísticamente significativos ( $\mathrm{p} \leq 0,001$ y $\mathrm{p} \leq 0,044$ respectivamente) y en el grupo control de Xilopercha se observó diferencia significativa entre los valores de la suma de células inflamatorias entre los períodos de 3-5 días $(\mathrm{P} \leq 0,05)$. De acuerdo a los resultados, puede concluirse que ambos materiales, AgTM y MRRE causaron una reacción inflamatoria que disminuyó a través del tiempo, sugiriendo que ambos materiales son biocompatibles; mostrando sin embargo una mayor organización de fibras colágenas alrededor de los implantes de MRRE.

PALABRAS CLAVE: Materiales restauradores; Agregado de trióxido mineral blanco; biocompatibilidad; Material de Reparación de la Raíz Endodóntica.

\section{REFERENCES}

Camilleri, J. \& Pitt Ford, T. R. Mineral trioxide aggregate: a review of the constituents and biological properties of the material. Int. Endod. J., 39(10):747-54, 2006.

Chong, B. S. \& Pitt Ford, T. R. Root-end filling materials: rationale and tissue response. Endod. Top., 11(1):114-30, 2005.

Ciasca, M.; Aminoshariae, A.; Jin, G.; Montagnese, T. \& Mickel, A. A comparison of the cytotoxicity and proinflammatory cytokine production of EndoSequence root repair material and ProRoot mineral trioxide aggregate in human osteoblast cell culture using reverse-transcriptase polymerase chain reaction. J. Endod., 38(4):486-9, 2012.

Damas, B. A.; Wheater, M. A.; Bringas, J. S. \& Hoen, M. M. Cytotoxicity comparison of mineral trioxide aggregates and EndoSequence bioceramic root repair materials. J. Endod., 37(3):372-5, 2011.

Hammad, H. M.; Hamadah, M. A. \& Al-Omari, W. M. Histological evaluation of rat tissue response to GMTA, Retroplast, and Geristore retrograde filling materials. Aust. Endod. J., 37(1):18-25, 2011.
Khashaba, R. M.; Moussa, M. M.; Chutkan, N. B. \& Borke, J. L. The response of subcutaneous connective tissue to newly developed calcium phosphate-based root canal sealers. Int. Endod. J., 44(4):342-52, 2011.

Ma, J.; Shen, Y.; Stojicic, S. \& Haapasalo, M. Biocompatibility of two novel root repair materials. J. Endod., 37(6):793-8, 2011.

Morse, D. R.; Martell, B.; Pike, C. G.; Fantasia, J.; Esposito, J. V. \& Furst, M. L. A comparative tissue toxicity evaluation of Gutta-percha root canal sealers. Part I. Six-hour findings. J. Endod., 10(6):246-9, 1984.

Morse, D. R.; Martell, B.; Pike, C. G.; Fantasia, J.; Esposito, J. V. \& Furst, M. L. A comparative tissue toxicity evaluation of Gutta-percha root canal sealers. Part II. Forty-eight-hour findings. J. Endod., 10(10):484$6,1984$.

Olsson, B.; Sliwkowski, A. \& Langeland, K. Subcutaneous implantation for the biological evaluation of endodontic materials. J. Endod., 7(8):355-67, 1981.

Parirokh, M. \& Torabinejad, M. Mineral trioxide aggregate: a comprehensive literature review--Part III: Clinical applications, drawbacks, and mechanism of action. J. Endod., 36(3):400-13, 2010.

Parirokh, M.; Mirsoltani, B.; Raoof, M.; Tabrizchi, H. \& Haghdoost, A. A. Comparative study of subcutaneous tissue responses to a novel rootend filling material and white and grey mineral trioxide aggregate. Int. Endod. J., 44(4):283-9, 2011.

Shahi, S.; Rahimi, S.; Lotfi, M.; Yavari, H. \& Gaderian, A. A comparative study of the biocompatibility of three root-end filling materials in rat connective tissue. J. Endod., 32(8):776-80, 2006.

Shokouhinejad, N.; Nekoofar, M. H.; Razmi, H.; Sajadi, S.; Davies, T. E.; Saghiri, M. A.; Gorjestani, H. \& Dummer, P. M. Bioactivity of EndoSequence root repair material and bioaggregate. Int. Endod. J., 45(12):1127-34, 2012.

Yaltirik, M.; Ozbas, H.; Bilgic, B. \& Issever, H. Reactions of connective tissue to mineral trioxide aggregate and amalgam. J. Endod., 30(2):959, 2004.

Corresponding author:

PhD. Jairo Mariel Cárdenas

Department of Morphology

Faculty of Dentistry

University of San Luis Potosí

Av. Manuel Nava 2

San Luis Potosí, S.L.P.

MEXICO

Email: Ilairo@yahoo.com.mx

Received: 20-09-2018

Accepted: 01-03-2019 